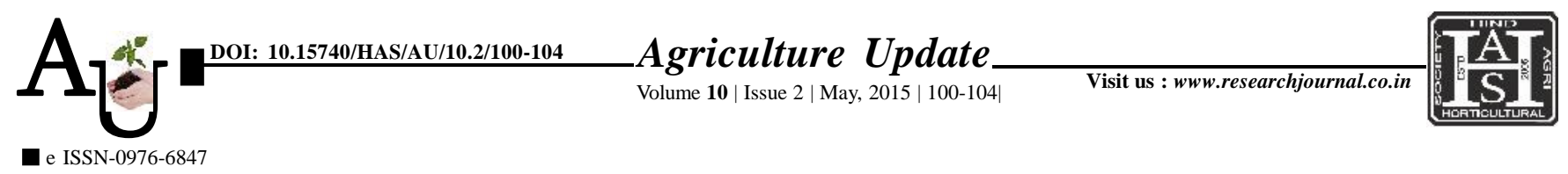

\title{
Research Article: Relationship between aspirations and personal, socio-economic and psychological characteristics of rural youth and constraints faced by rural youth towards self development
}

Article Chronicle: Received : 23.08.2014;

Revised : 06.03.2015;

Accepted :

20.03.2015

KeY WoRds : Aspiration, Self development, Constraints

Author for correspondence :

\section{M.D. MALI}

Extension Education Section, Post Graduate Institute, Mahatma Phule Krishi Vidyapeeth, Rahuri, AHMEDNAGAR (M.S.) INDIA

Email: mehjabin1323@ gmail.com

See end of the article for authors' affiliations

\section{M.D. MALI*, V.S. TEKALE AND J.I. SHAIKH}

SUMMARY : The present research on relationship between aspirations and personal, socio-economic and psychological characteristics of rural youth was conducted in Ramtek and Kamthi taluka of Nagpur district of Maharashtra State. 100 youth were selected randomly from 10 villages. The data were collected by personal interview from rural youth with the help of interview schedule. In case of relationship of selected characteristics of respondents with their role in village development age, education, experience in farming, family size, land holding, social participation, extension contact, mass media exposure and cosmopoliteness were found to be positively and significantly correlated with overall role of rural youth in village development. Mostly the respondents faced constraints in village development like low price return from farm produce $(90.00 \%)$, lack of electricity and irrigation water $(73.00 \%)$, lack of labour for performing farm operations $(70.00 \%)$ and lack of knowledge about improved farm technologies $(67.00 \%)$.

How to cite this article : Mali, M.D., Tekale, V.S. and Shaikh, J.I. (2015). Relationship between aspirations and personal, socio-economic and psychological characteristics of rural youth and constraints faced by rural youth towards self development. Agric. Update, 10(2): 100-104. 